\title{
A BÚZA DON-TOXIN VÁLTOZÁSA A MALOMIPARI TISZTÍTÁSI FOLYAMATBAN
}

\author{
Kecskésné Nagy Eleonóra - Nagy József - Osztényiné Krauczi Éva - \\ Sembery Péter
}

\begin{abstract}
Absztrakt: A kutatás során azt vizsgáltuk technológiai környezetben, hogy ha optikai válogatást és korszerü felülettisztítást együttesen alkalmazunk a malomipari tisztítási folyamatban, akkor hogyan változik a búzaminták toxinszennyezettsége. Három évjáratban betakarított búzatételek esetén gyüjtöttünk adatokat arra vonatkozóan, hogy a Sortex Z+ optikai válogató és a Schule Verticone VPC 480 felülettisztító gépek együttes alkalmazásával csökkenthető-e a búzatételek vizsgálati mintáinak a toxintartalma. A leíró statisztika egyértelműen azt mutatta, hogy a tisztítási folyamat végére minden évjáratban a vizsgált búzaminták átlagos toxinszintje csökkent. Az induktív statisztikával pedig azt állapítottuk meg, hogy 95\%-os valószínüségi szinten a búzatételek esetén igaz is az előző megállapítás. Vagyis a vizsgált évjáratokban, ha a tisztítási folyamatban az említett korszerü berendezéseket alkalmazzák malomipari örlés elött, csökkenthetö a búzatételek DON-toxin szennyezettsége.
\end{abstract}

Abstract: In the course of the research we examined in a technological environment that if we use optical sorting and modern surface cleaning in the mill cleaning process, how does the toxin contamination of wheat samples change. We collected data on harvested wheat grains in three years to determine if the toxin content of corn samples can be reduced by the combined use of Sortex Z optical sorting and Schule Verticone VPC 480 surface cleaning machines. Descriptive statistics clearly showed that at the end of the purification process the average toxin level of the tested wheat samples decreased in every year. And with inductive statistics at $95 \%$ probability level, we found that the previous statement is true for wheat lots also. That is, in the case of the examined years in the purification process in which mentioned modern equipments are used, the contamination of the DON toxin of wheat lots can be reduced before milling.

Kulcsszavak: DON-toxin, malmi tisztítás, optikai válogatás, felülettisztítás

Keywords: DON-toxin, mill cleaning process, optical sorting, surface cleaning

\section{Bevezetés}

Az elmúlt években a búzatermesztésben és feldolgozásban komoly veszteségeket okoztak a Fusarium nemzetségbe tartozó, számos toxin termeléséért felelős gombafajok. A fuzariotoxinok egyik gyakran előforduló képviselöje a deoxinivalenol, vagy vomitoxin, még ismertebb nevén DON-toxin (Kiss-Toldi, 2013). Mesterházy (2007) szerint a búzában ez a toxin fordul elő leggyakrabban. E toxin élelmiszerbiztonsági szempontból jelentősnek mondható, mert nagyon stabil vegyület, hőhatásnak ellenáll, a tárolási és a feldolgozási folyamatok során sem bomlik le, tehát az egész élelmiszerláncon képes végighaladni, és az emberi szervezet megbetegedését okozza (Sohár, 2007; Ambrus-Szeitzné, 2010). Ebből eredően az Európai Unióban a 1881/2006/EK rendelet rögzíti e szennyező anyag felső határértékét az élelmiszerek alapanyagainál és az élelmiszereknél. Ez az érték a feldolgozatlan durumbúza esetén 1,75 ppm.

A gabonák fuzárium fertőzésének és a toxinszennyezettség mértékének az alakulásában kiemelt szerepe van az időjárási tényezőknek, vagyis az évjárathatásnak. Ez olyan kockázati faktor, amire a búza termesztése során nincs 
ráhatása a termesztőknek (2006/583/EK irányelv; Mesterházy, 1995). A gombafertőzés a gabonaszem egyes rétegeiben eltérő mértékủ lehet, attól függően, hogy a virágzás-termésképzés mely szakaszában történik az infekció, azaz mely fenofázisban válnak kedvezővé ehhez az időjárási feltételek (Veres-Borbély, 2007). Így a DON-toxin szennyezettség mértéke is változhat a búzaszem különböző részeiben, vagyis eltérő lehet a héjrétegekben, a termőszövetben és a csírában. A fertőzés következtében megváltozhat a magvak színe, alakja vagy tömege. E jelenségeknek a kísérletünk szempontjából van szerepe.

Fontos élelmiszerbiztonsági kérdés a malomipari feldolgozás során, hogy a termesztést követő lépésekben van-e lehetőség a búzatételek DON-toxin tartalmának a csökkentésére. A hagyományos malmi technológiák kapcsán több szerző tesz olyan megállapítást, miszerint a feldolgozási folyamatban már nem lehet hatásosan csökkenteni a toxintartalmat (Brera és mtsai, 2013; Szabó-Hevér, 2013; Szeitzné, 2009; 2006/583/EK irányelv). Sándor és munkatársai (2010), valamint Frank (2010) közel azonos módon felépített modellkísérleteket végeztek a DON-toxin csökkentésére, amelyben igazolták, hogy a felülettisztítás hatásos lehet a toxincsökkentésben. A felülettisztítás toxincsökkentő hatását vizsgálták Kushiro (2008) valamint Véha és munkatársai (2011) is, és egy adott módszer eredményességét igazolták. Ezek fontos eredmények, viszont a modellkísérletek nem tudják a termelés-gyártás során előforduló sajátosságokat teljes mértékben leképezni. Hiszen a malmokban különböző mikro- és makroklimatikus tényezőknek kitett búzatételeket dolgoznak fel. Ez befolyásolja a fuzárium fertőzés és a toxinszennyződés jellegét, illetve mértékét a termőhelytől és évjárathatástól függően (Veres-Borbély, 2007). Tehát fontos megvizsgálni, hogy feldolgozási körülmények között is lehet-e megfelelő biztonsággal csökkenteni az őrlésre szánt tételek toxintartalmát függetlenül attól, hogy a búzatermesztés milyet technológiai és ökológiai tényezők között zajlott.

\section{Anyag és módszer}

A durumbúza örlés előtti tisztítási folyamatának a vizsgálatát a DON-toxin tartalom csökkenésére, számítógépes vezérléssel rendelkező, korszerü malomipari környezetben végeztük, ahol a gyártási folyamat jól lekövethető. Kísérlet kialakítása abban tért el a szakirodalomban a felülettisztítás hatását vizsgáló modellkísérletektől, hogy nem mesterséges fertőzés által, hanem termesztési körülmények során kialakult, különböző mértékű toxinszennyezettség csökkentési lehetőségét vizsgáltuk. E mellett a malomban alkalmazott technológiai beállításnak megfelelő körülmények között kísértük figyelemmel a toxincsökkenés mértékét. Igazolva, hogy egy korszerü technológiát alkalmazó gyártás során, e jelentős élelmiszerbiztonsági kockázat a gyakorlatban megbízhatóan csökkenthető.

A vizsgált alapanyag durumbúza, aminek egy-egy alkalommal mintegy 48 tonna, ismert termelési helyről származó tételeit vizsgáltuk. Ezen felül a feldolgozás során, az alapanyag pontos nyomon- és lekövetését több tényezö segítette. A durummalom szakaszos üzemelésü, a kísérletben vizsgált búzatételek mindegyike a malmi silóban mintegy 3 méteres oszlopmagasságot képviselt, ami a silóból négy 
kifolyónyíláson keresztuil ürült ki. A kísérleti minták megszedésének idején egalizálás nem történt.

Egy mintavételi napon egy tételt mintáztunk meg közvetlen az optikai válogató gép előtt $\left(\mathrm{V}_{1}\right)$ és a válogatás után $\left(\mathrm{V}_{2}\right)$, illetve a felülettisztító gép előtt és után ( $\mathrm{V}_{4}$ és $\mathrm{V}_{5}$ minták) (1. ábra). Négy mintavételi hely adatai alapján kísértük figyelemmel a toxinváltozást, amiből e dolgozatban a kiinduló és a tisztítás végén mérhető toxintartalom alakulását értékeltük ki a $V_{1}$ és a $V_{5}$ minták alapján. Minden mintavételi helyen egy tételből négy almintát vettünk. Tehát tételenként összesen 16 almintának vizsgáltuk be a toxintartalmát. Ez lehetővé tette a centrális határeloszlás tétel alkalmazását, ami a korrekt statisztikai kiértékelést segítette.

\section{1. ábra: Mintavételezés rendje}

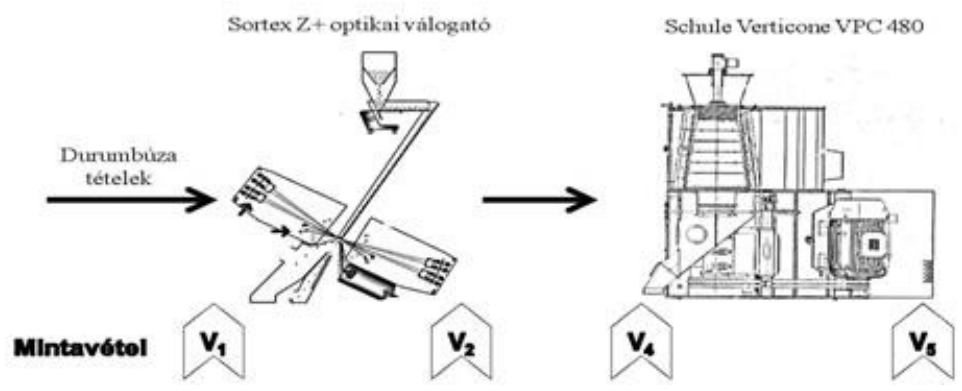

A tételekhez tartozó alminták eredményeit mintavételi helyenként átlagoltuk, majd a kiértékelést az átlagértékekkel végeztük. A 2013. évben 656 alminta adatai alapján 41 tétel, 2014-ben betakarított búzából 1024 alminta adatai alapján 64 tétel, míg a 2015-ös évjáratból 944 alminta adatai alapján 59 tétel vizsgálati eredményeit értékeltük.

A DON-toxin laboratóriumi meghatározása a malmokban széles körben elterjedt, üzemi körülmények között is egyszerủen kezelhetö, a mikotoxin vizsgálatok esetében gyors és megbízható eredményt produkáló ELISA teszttel történt. A módszer nagy előnye, hogy a gabona felhasználásának a helyén kaphatunk nagyon pontos és rövid idő alatt rendelkezésre álló adatokat. A mérési tartomány a feldolgozás élelmiszerbiztonsági feltételeinek biztosításához megfelelő. A tesztkitt jellemzői között szerepelnek: a kimutatási határ (LOD) 0,2 ppm, a mennyiségi meghatározás alsó határa (LOQ) 0,25 ppm és a mennyiségi meghatározás legfelső határa, ami 5 ppm.

E publikációban az optikai válogatás és a felülettisztítás toxinváltozásra gyakorolt együttes hatását értékeltük ki. Az adatok feldolgozásához deskriptív (leíró) és induktív statisztikai módszereket alkalmaztunk. A deskriptív statisztika a mintapárokban $\left(\mathrm{V}_{1}-\mathrm{V}_{5}\right)$ bekövetkezett változásokat és összefüggéseket mutatta meg, az induktív statisztika hipotézisvizsgálataival pedig a statisztikai populációra vonatkozóan vontunk le következtetéseket. Az induktív statisztikát megelőző normalitás vizsgálatok azt mutatták, hogy az összetartozó mintapárok közül nem mindegyik volt normális eloszlású. Így a hipotézisvizsgálatokhoz a teszteket ennek megfelelően határoztuk meg. A négy mintavételi hely mintáinak együttes értékelésére Friedman próbát és varianciaanalízist használtunk. 


\section{Eredmények és értékelésük}

3.1. A teljes tisztítási folyamat elemzése leíró statisztikai módszerekkel

A leíró statisztika grafikonjain látható, hogy a különböző évjáratban betakarított búzaminták kiinduló toxintartalma eltér egymástól (2., 4., 6. ábrák).

A 2013. évjáratban betakarított búzák teljes tisztítási folyamatának eredményességét a 2. ábra szemlélteti. A mintapárokat ábrázoló oszlopdiagram azt mutatja, hogy a tisztítási folyamat végére jelentősen csökkent a búzaminták toxintartalma. Az eredményeket vizsgálva az látszik, hogy ebben az évben a búzaminták kiinduló toxinszennyezettsége ( $\mathrm{V}_{1}$ minták) viszonylag kiegyenlített volt. A 2013-ban betakarított búzák toxintartalma közepes értéknek mondható. A mintákban 0 ppm-et nem mértünk, a legalacsonyabb érték $0,14 \mathrm{ppm}$. Az adatok többsége az átlag körül mozog, nagy szórást nem mutat. Egyedül az ábrán a 41. számot kapott minta koncentrációja kimagasló: 1,96 ppm. Az adatok többsége (80\%a) 0,6-1,5 ppm között mozog.

A tisztítás után a mikotoxin tartalom csökkenés mértéke nagy változatosságot mutat ( $\mathrm{V}_{5}$ minták). A 2013. évi mintákban az átlagos toxincsökkenés 0,55 ppm, ebböl az következik, hogy csaknem 47\%-al, vagyis 53\%-ra csökkent a DON-toxin tartalom a teljes tisztítási folyamatnak köszönhetően a mintákban.

\section{2. ábra: A búzaminták kiinduló (V1) és a teljes tisztítási folyamatot követő (V5) DON-toxin koncentrációja (2013. évi betakarítás)}

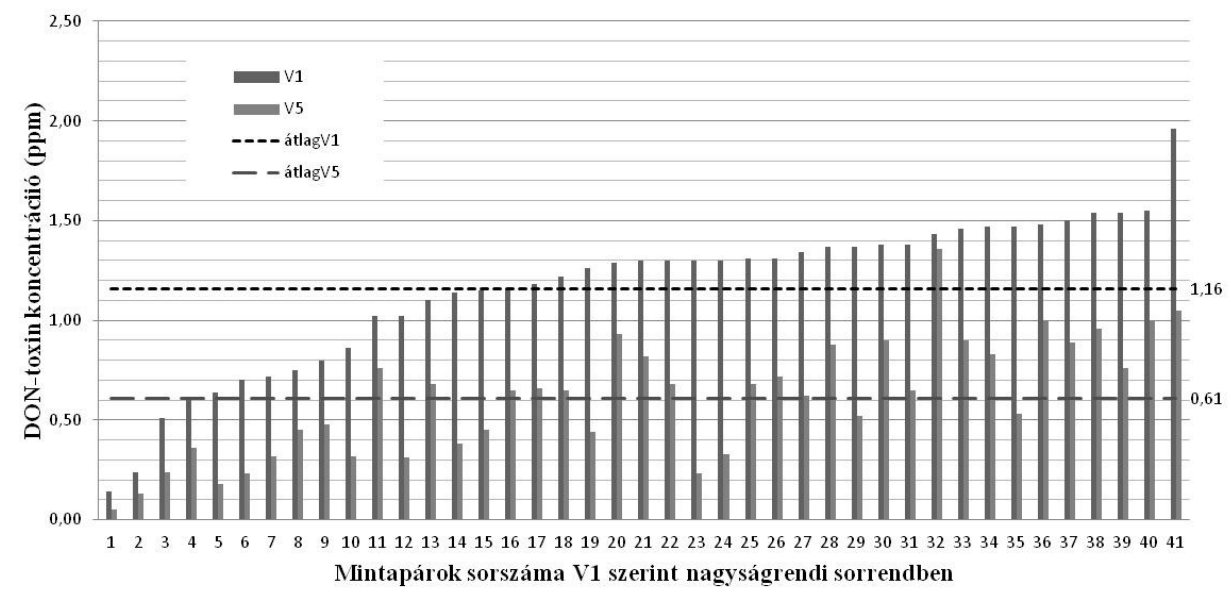

Forrás: a szerző saját szerkesztése

A $V_{5}$ mintavételi hely mintáinak változatos alakulása abból adódik, hogy nem egyenletesen és nem arányosan tudta az optikai válogatás és a felülettisztítás együttesen levinni a toxinszintet az egyes mintáknál. A legkisebb mértékü csökkenés 0,07 ppm, aminek a kiinduló toxinszintje 1,43 ppm (2. ábra 32. minta). Ennél a mintánál a legkevésbé hatásos a tisztítás, mert a kezdeti toxintartalmat 5\%-al lehetett csupán csökkenteni. A legnagyobb mértékü változás pedig 1,07 ppm, aminek a kiinduló szintje 1,30 ppm (2. ábra 23. minta). Az adatok alakulásából az látható, 
hogy nem a legkisebb kiinduló toxinszint eredményezi a legkisebb mértékü csökkenést. Viszont ennek a megállapításnak az inverze is igaz, hogy nem a legnagyobb kezdeti toxintartalom változik a legnagyobb mértékben. Tehát, ha a mintákat egyedileg vizsgáljuk, a 2013. évi adatok azt igazolják, hogy a kiinduló toxinszinttel nem arányosan csökken a tisztított búza kémiai szennyezettsége. A szakirodalomban olvasható erre vonatkozóan elméleti okfejtés, amit a kutatási eredményeimmel alá tudtam támasztani. Ha általános érvényü, a teljes statisztikai sokaságra, vagyis a búzatételekre igaz, korrekt megállapítást szeretnék tenni, azt csak az induktív statisztikai módszerekkel végzett adatértékelést követően lehet megtenni.

Jól szemlélteti a DON-toxin változást a gyakorisági diagram (3. ábra). A koordinátarendszer $\mathrm{x}$-tengelyén öt intervallumot alakítottunk ki a DON-toxin koncentráció értékeinek a csoportosításával. Az első négy intervallum a jogszabályi határértéket négy egyenlő részre osztja, az ötödikbe a határérték feletti minták kerültek. A számadatok alapján meghatároztuk, hogy egy-egy intervallumba a vizsgált minták közül hány darab sorolható be. Látszik, hogy a $\mathrm{V}_{1}$ mintavételi hely mintáinak több mint a fele a 1,25-1,75 ppm-es értéktartományba esett. Ami elvileg az egészséget nem veszélyeztető, de az emberi szervezet számára szükségtelen terhelést okozó érték. Viszont a tisztítási folyamat végén a $V_{5}$ mintavételi hely mintáinak több mint a 75\%-a a jogszabályi határérték felénél kevesebb toxint tartalmaz, ami a gyártás biztonságát növeli.

\section{3. ábra: Gyakorisági diagram a $V_{1}$ és $V_{5}$ mintavételi helyek mintáinak toxinváltozására a teljes tisztítási folyamatban (2013. évjárat)}

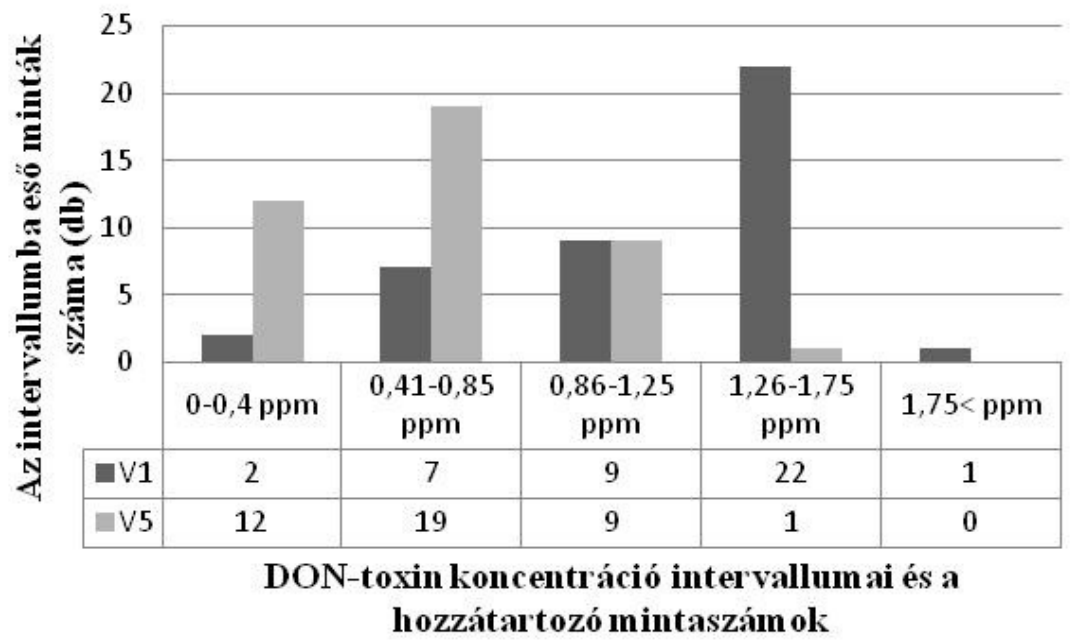

Forrás: a szerző saját szerkesztése

A fenti eredmény azért kiemelten fontos, mert mint tudjuk, a búzából készült termékek nagy része alapvető élelmiszer, vagyis a lakosság nagy mennyiségben fogyasztja azokat. Tegyük ehhez hozzá, hogy az étkezés révén megvan az eshetősége annak, hogy egyéb kémiai összetevőket is bevihetünk a szervezetbe, amelyek élettani 
szempontból kedvezőtlen hatást gyakorolhatnak. Bár a jogszabályi határértékek megfelelő biztonságot jelentenek a fogyasztók számára, mégis célszerü minimalizálni e kockázati tényezők mennyiségét az egészség megőrzése érdekében, mert az említett kémiai anyagok szervezetre gyakorolt hatása összeadódhat. Összességében az eredmények egyértelmüen jelzik, hogy ebben az évjáratban a tisztítással abszolút biztonságossá lehetett tenni a malmi búzatételeket.

A 2014. évi betakarításból származó búzaminták átlagos toxincsökkenése 0,34 ppm (4. ábra). Vagyis a $\mathrm{V}_{1}$ mintavételi hely átlagmintájához képest a $\mathrm{V}_{5}$ mintavételi hely mintáinak az átlaga 53\%-os értéket mutat, hasonlóan a 2013. évi adatokhoz. A minták átlagértékei szerint ebben az évjáratban a búzák tisztítás előtti DON-toxin koncentrációja alacsonyabb volt, mint 2013-ban. A kiinduló átlagkoncentráció 0,72 ppm (2013-ban 1,16 ppm), a tisztítás után pedig 0,38 ppm (2013-ban 0,61 ppm). Ez abból adódik, hogy a minták több mint $73 \%$-ának a bemeneti $\left(\mathrm{V}_{1}\right.$ minták) toxinszintje nagyon alacsony, pontosabban $0,83 \mathrm{ppm}$ alatti. A maradék 27\% 1,051,81 ppm közé esik, a legalacsonyabb érték 0,28 ppm.

\section{4. ábra: A búzaminták kiinduló ( $\left.\mathbf{V}_{1}\right)$ és a teljes tisztítási folyamatot követő ( $\left.\mathbf{V}_{5}\right)$ DON-toxin koncentrációja (2014. betakarítás)}

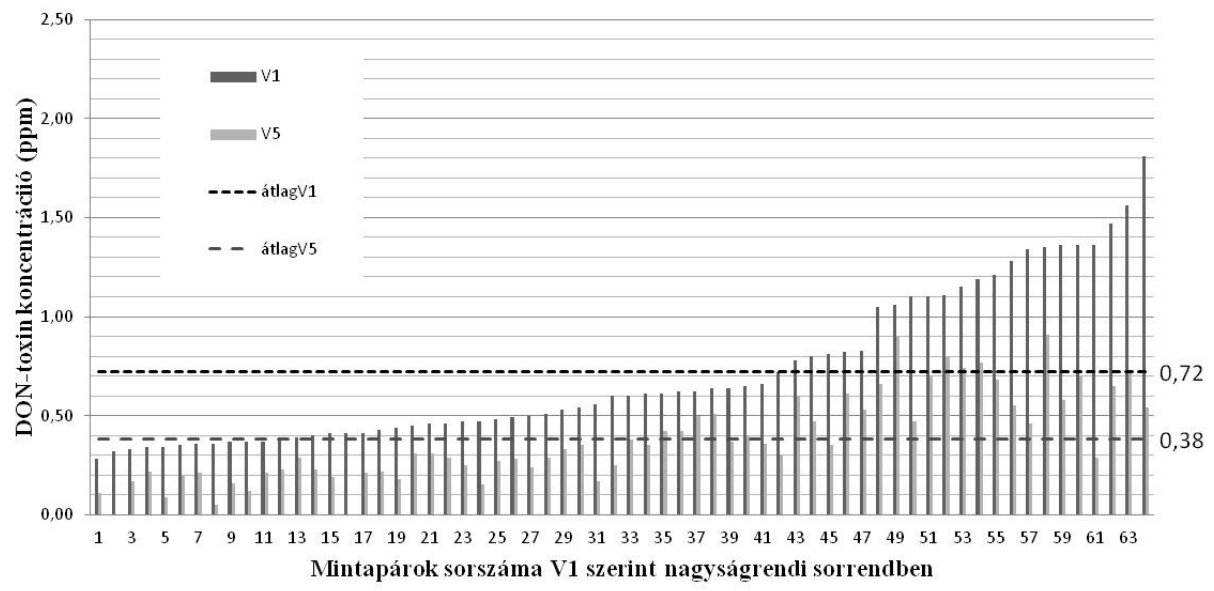

Forrás: a szerző saját szerkesztése

A tisztítást követő mintákban ( $\mathrm{V}_{5}$ mintavételi hely) a DON-toxin tartalom ebben az évben is nagy változatosságot mutat. A legnagyobb mértékü toxincsökkenés 1,27 ppm, aminek a kiinduló toxinszintje a legmagasabb éves adat, 1,81 ppm (4. ábra 64. számmal jelölt minta). Így ennek a mintának igen alacsony szintre, 0,54 ppm-re (30\%-ra) lehetett levinni a tisztítás során a DON-toxin tartalmát. A legkisebb mértékü toxincsökkentést $0,10 \mathrm{ppm}$-el a 4. ábra 13. mintájánál értük el. A tisztítás legrosszabb hatékonyságú a 4. ábra 49. mintájánál volt 0,15 ppm-el, ami a kiinduláshoz képest mindösszesen 14\%-os csökkenést jelent. A 2014. évi mintáknál a 4. ábra oszlopdiagramja jó közelítéssel azt mutatja, hogy a legnagyobb kiinduló DON-toxin tartalmú minták esetén a tisztítás nagyobb mértékü csökkenést idézett 
elö. Ez eltérés a 2013-as évjáratban betakarított búzatételeknél tapasztaltakhoz képest.

A gyakorisági diagram ebben az évjáratban is jelzi, hogy nagy arányban lehetett növelni a tisztítás után azoknak a mintáknak a számát, amelyek alacsonyabb toxintartalmúak lettek (5. ábra). Bár 2014-ben már a tisztítást megelőzően is $\left(\mathrm{V}_{1}\right.$ mintavételi hely) a minták nagyobb darabszáma esett a kisebb DON-toxin tartományba, azaz 73\%-a 0,85 ppm alatti. De a teljes tisztítási folyamat után $\left(\mathrm{V}_{5}\right.$ mintavételi hely) a minták csaknem 97\%-a került ebbe az intervallumba. A $\mathrm{V}_{5}$ mintavételi hely mintáinak a 63\%-a 0,40 ppm alatti értéket mutat. Ez kifejezetten alacsony értéktartomány.

\section{5. ábra: Gyakorisági diagram a V1 és $V_{5}$ mintavételi hely mintáinak toxinváltozására a teljes tisztítási folyamatban (2014. évjárat)}

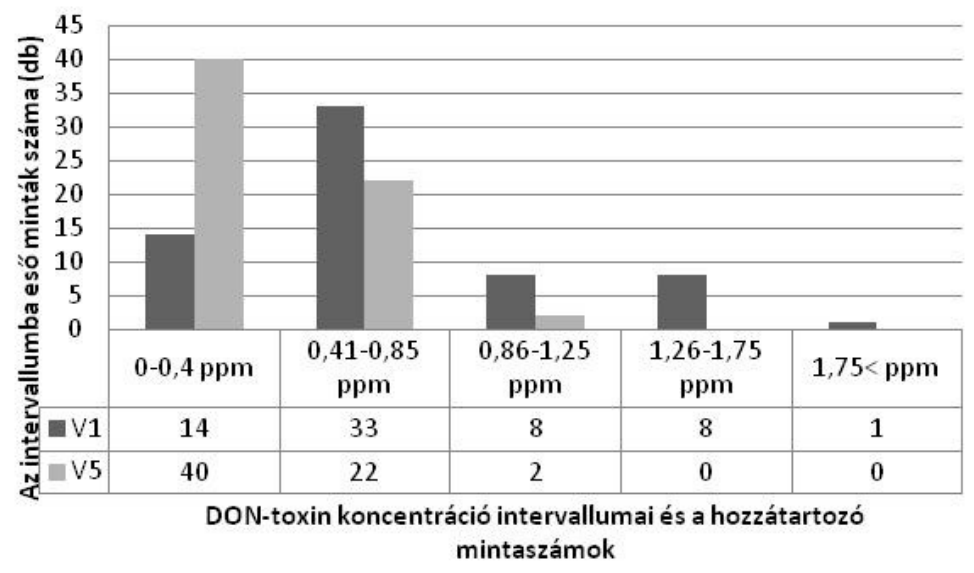

Forrás: a szerző saját szerkesztése

A 2015-ös évben a számadatok azt mutatják, hogy a kiinduló toxinszint átlaga $1,20 \mathrm{ppm}$ (6. ábra). Az előző két év adataival összehasonlítva ez az érték a legmagasabb. Bár a 2013-ban mért adathoz (1,16 ppm) képest mérsékelt az emelkedés. A teljes kép kialakítása érdekében érdemes összehasonlítani a 2 . és a 6. ábrákat. Ebből az látszik, hogy az átlagértékek mögött az adatok alakulásának eltérö tendenciája húzódik meg. Amíg 2013-ban kiegyenlített a minták toxintartalma, addig 2015-ben nagyobb a szórás, azaz az átlagértéktől való eltérés. A 6. ábrát vizsgálva a legalacsonyabb toxinkoncentráció $0,32 \mathrm{ppm}$, a legmagasabb 1,80 ppm. Az átlagos toxinkoncentrációt $0,61 \mathrm{ppm}$-el tudtuk csökkenteni, vagyis azt 49\%-ra lehetett levinni a tisztítási folyamattal. A három évjárat közül ez a legnagyobb csökkenési arány. Tehát az átlagadatok azt mutatják, hogy a relatíve magasabb toxinkockázatú évjáratban a tisztítás hatásfoka jobbnak bizonyult a malmi búza mintáinál. 
6. ábra: A malmi búza mintáinak a kiinduló $\left(\mathrm{V}_{1}\right)$ és a teljes tisztítási folyamatot követő ( $\left.V_{5}\right)$ DON-toxin koncentrációja (2015. betakarítás)

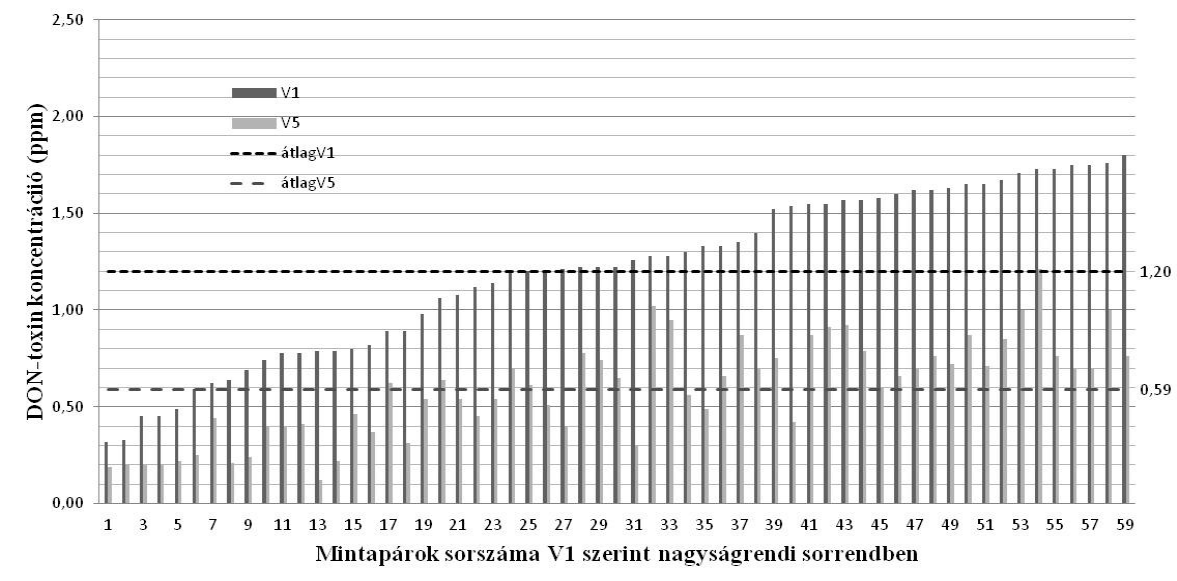

Forrás: a szerző saját szerkesztése

2015-ben a tisztítási folyamatot követően a malmi búzaminták toxintartalmát, kettő kivételével 1 ppm alá lehetett csökkenteni, ami teljes biztonságot tud nyújtani ahhoz, hogy a jogszabályi határérték alatti lisztet tudjanak őrölni a malomban. Ebből a két mintából az egyik alig haladta meg az 1 ppm-et, míg a másik kevéssel felette, $1,20 \mathrm{ppm}$ értéket vett fel. Ebben az évben is voltak olyan mintáink, amelyeknél nagyon kismértékü toxincsökkenést lehetett elérni a halmaz és felülettisztítás együttes alkalmazásával: 6. ábra 1-es mintánál 0,13 ppm, a 6. ábra 7-es mintánál $0,18 \mathrm{ppm}$. Míg a legnagyobb mértékü, 1,04 ppm toxincsökkenés a 6. ábra 59-es mintájánál volt mérhető. Ez viszont mutatja, hogy a magasabb toxintartalmú búzamintáknál az optikai válogatás és a felülettisztítás együttes alkalmazása igen jelentős toxincsökkenést ért el ebben az évjáratban.

\section{7. ábra: Gyakorisági diagramok a $V_{1}$ és $V_{5}$ mintavételi helyek mintáinak} toxinváltozására a teljes tisztítási folyamatban (2015. évjárat)

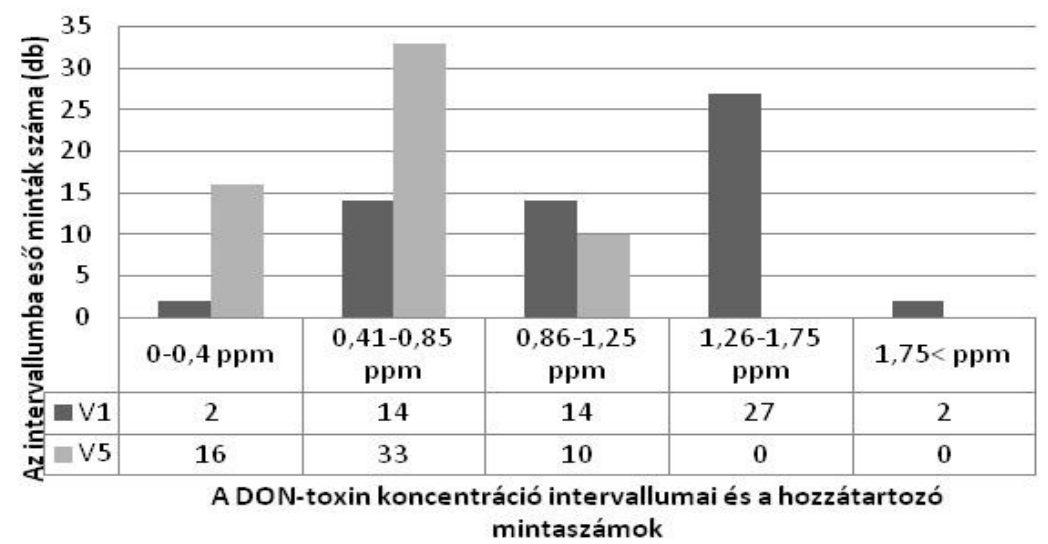

Forrás: a szerző saját szerkesztése 
A gyakorisági diagram (7. ábra) szintén azt mutatja, hogy a tisztítás hatékonysága megfelelő volt a 2015. évjáratban. Az örlésre kerülő 59 búzatétel $V_{1}$ mintavételi helyeiről származó minták 73\%-a a jogszabályi határérték felénél több DON-toxint tartalmaz, azaz a magasabb toxin-szennyezettségü csoportba sorolhatóak. A halmaz és a felülettisztítás után viszont a minták 83\%-ában a jogszabályi határérték felénél kevesebb toxinszennyeződés maradt, ami élelmiszerbiztonsági szempontból igen kedvező feltételeket biztosít a liszt előállításához.

\subsection{A teljes tisztítási folyamat hipotézisvizsgálata}

Az induktív statisztikai vizsgálatokkal arra keressük a választ, hogy a leíró statisztika mintavizsgálati eredményei kiterjeszthetők-e a teljes statisztikai populációra, azaz a búzatételekre. Vagyis $95 \%$-os valószínűségi szinten igazolható-e az egyes évjáratokban az optikai válogatás és a korszerü felülettisztítás DON-toxin csökkentő hatása az alapanyagtételekben is.

Az induktív statisztikai kiértékelés esetén, ha a normalitást illetően szigorúak vagyunk, akkor a 2. fejezetben leírtak miatt, a négy összetartozó mintát a Friedmanpróba segítségével kell vizsgálni, mert ennek nem feltétele az adatok normális eloszlása. A Friedman-próba $\mathrm{H}_{0}$ hipotézise, hogy mind a négy minta eloszlása megegyezik. A próba tesztstatisztikája, egy (4-1) szabadsági fokú aszimptotikusan $\chi^{2}$-eloszlású véletlen mennyiség.

Az 1. táblázat azt mutatja, hogy mind a három évjáratban a statisztikai érték jóval nagyobb a kritikus értéknél, ezért a nullhipotézist el kell vetni. Vagyis nem azonosak az eloszlások, tehát az őrlést megelőző tisztítási folyamatban statisztikailag is igazolhatóan változott a búzatételek DON-toxin tartalma. E teszt szerint az optikai válogatást és a korszerü felülettisztítást alkalmazva a malmi folyamatban, a 2013ban, a 2014-ben és a 2015-ben betakarított alapanyagtételeknél csökkenteni lehetett a toxintartalmat. Ebből azt a következtetést vonhatjuk le, hogy amit a leíró statisztikában mutattak a minták adatai, általános érvényünek tekinthető a teljes statisztikai sokaságra.

\section{1. táblázat: A Friedman-próba eredménye a különböző évjáratokban betakarított búzaminták esetén}

\begin{tabular}{||c||c|c|c||}
\hline Évjárat & $\mathbf{2 0 1 3 .}$ & $\mathbf{2 0 1 4 .}$ & $\mathbf{2 0 1 5 .}$ \\
\hline $\begin{array}{c}\text { Statisztikai } \\
\text { érték }\end{array}$ & 105,62 & 158,01 & 174,95 \\
\hline $\begin{array}{c}\text { Kritikus } \\
\text { érték }\end{array}$ & & 7,81 & \\
\hline
\end{tabular}

Forrás: a szerző saját szerkesztése

Bár az adatok nagyon meggyőzőek, mert a statisztikai és a kritikus értékek között igen nagy eltérés mutatkozik, fontos, hogy további vizsgálatokkal igazoljuk az 
állítást, mivel a Friedman-próba megengedőbb statisztikai módszernek tekinthető. Ezért elvégeztük az adatelemzést varianciaanalízissel is.

A varianciaanalízis egyik feltétele a normalitás, de a robusztusságra hivatkozva alkalmazható ebben az esetben. Az analízis másik feltétele a szfericitás, amit vizsgálnunk kell a Mauchly teszt segítségével. A Mauchly tesztnek a nullhipotézise, hogy a szórások tökéletesen megegyeznek. Az $\alpha=0,05$ szignifikanciaszinthez tartozó kritikus érték mindhárom esetben 0,377 . A tesztstatisztika értékei az alábbiak szerint alakulnak:

- a 2013-ban betakarított búza mintáira vonatkozóan 0,0016,

- a 2014-ben betakarított búza mintáira vonatkozóan 0,0014,

- a 2015-ben betakarított búza mintáira vonatkozóan 0,0012.

Akkor fogadjuk el a $\mathrm{H}_{0}$ hipotézist, ha a tesztstatisztika értéke kisebb a kritikus értéknél. Az eredmények egyértelmüen jelzik, hogy azonosnak tekinthetjük a szórásokat, tehát a szfericitás teljesült, így a varianciaanalízist nyugodtan alkalmazhatjuk.

A varianciaanalízis nullhipotézise megegyezik a Friedman-próba nullhipotézisével, de ebben az esetben a vizsgálati feltételek szigorúbbak. Tehát az eljárásnál a feltételek miatt ez a nullhipotézis valójában a várható értékek megegyezésével ekvivalens. A feltételek - azaz a normalitás és a szfericitás teljesülése esetén már csak a várható értékeknek kell egyezniük az eloszlások megegyezéséhez. A teszt statisztikája az alábbiak szerint alakul:

2013-ban betakarított búza esetén: egy (4-1); (41-1)*(4-1) szabadsági fokú F-eloszlású véletlen mennyiség, ami ebben az esetben az összetartozó mintákra vonatkozóan 101,40 értéket vett fel. A 95\%-os valószínüségi szinthez tartozó kritikus érték 2,68.

- 2014-ben betakarított búza esetén: egy (4-1); (64-1)*(4-1) szabadsági fokú F-eloszlású véletlen mennyiség, ami ebben az esetben az összetartozó mintákra vonatkozóan 79,88 értéket vett fel. A 95\%-os valószínüségi szinthez tartozó kritikus érték 2,65.

- 2015-ben betakarított búza esetén: egy (4-1); (70-1)*(4-1) szabadsági fokú F-eloszlású véletlen mennyiség, ami ebben az esetben az összetartozó mintákra vonatkozóan 159,61 értéket vett fel. A 95\%-os valószínűségi szinthez tartozó kritikus érték szintén 2,65.

Mivel a tesztstatisztika értéke mindhárom évjáratra vonatkozóan jóval nagyobb a kritikus értéknél, így megint el kell utasítani a nullhipotézist, azaz a minták eloszlása különböző. Megerősítette a teszt a Friedman-próba alapján tett megállapítást, miszerint az őrlés előtti közvetlen tisztítási folyamatnak van hatása a bemeneti alapanyag DON-toxin tartalmának a változására. Tehát mindkét statisztikai vizsgálatból az következik, hogy a válogatás és a felülettisztítás során módosul a DON-toxin szint eloszlása. A varianciaanalízis alapján az is elmondható, hogy ennek a szintnek az átlagos értéke változott. A Friedman-próba és a varianciaanalízis tehát megerősítette a leíró statisztika, vagyis a mintapárok adatainak lekövetése alapján meghozott feltételezésünket, és igazolta 95\%-os valószínüségi szinten, hogy a 
vizsgált tisztítási folyamatban csökken a búzatételek DON-toxin szintje az évjárathatástól függetlenül.

\section{Következtetések, javaslatok}

A kísérlet azt igazolta, hogy korszerủ malomipari technológiával, az alapanyagként használt durumbúza őrlés előtti tisztítása során, mind a három vizsgálati évben kellő biztonsággal csökkenthető volt a búzatételekben a DON-toxin tartalom. Vagyis a malmoknál e munkafázisban a korszerü optikai válogatás és felülettisztítás alkalmazásával az évjárathatástól függetlenül tudtuk a búzák toxinszintjét jelentősen mérsékelni.

A három évjáratban eltérő mértékü volt a vizsgálati tételek átlagos toxinszennyezettsége. A búzatételekből vett minták kiinduló DON-toxin koncentrációja 2015-ben volt a legnagyobb, ezt követte a 2013-as év, majd a legkisebb kiinduló toxin mennyiségeket a 2014. évben betakarított búzákban mértuik. Míg 2013-ban a minták DON-toxin tartalma az átlagérték körül alakult, addig 2014ben és 2015-ben nagyobb szórást mutattak az adatok. A kísérlet során a három évjáratban eltérő mértékü és jellegü toxinszennyezettség alakult ki.

A vizsgálati években a tisztítás után átlagosan 47-61 \%-ra lehetett csökkenteni a minták toxinszennyezettségét. Az adatok azt mutatták, hogy voltak olyan évjáratok, amikor a magasabb kiinduló toxinszint nagyobb arányban volt csökkenthető a tisztítás során. Azonban ez nem minden vizsgálati évben volt igazolható. Így érdemes a továbbiakban elemezni, hogy hogyan alakult az egyes mintákban egyedileg a tisztítás hatásfoka, hiszen ez arra adhat információt, hogy a szennyeződés jellege hogyan befolyásolja a feldolgozási folyamatban a tisztítás hatásosságát.

Az eredmények alapján kijelenthető, hogy érdemes a malmi tisztítási fázisba beépíteni, együttesen alkalmazni a Sortex Z+ optikai válogató és a Schule Verticone VPC 480 hántoló gépeket. A két gép alkalmazása lehetővé teszi az élelmiszerbiztonsági feltételek magasabb szintü biztosítását.

\section{Köszönetnyilvánítás}

A kutatás az EFOP-3.6.2-16-2017-00012 „Funkcionális, egészséges és biztonságos élelmiszer termékpálya modell kidolgozása a szántóföldtől az asztalig elv alapján, tematikus kutatási hálózatban" pályázat keretében valósult meg.

\section{Irodalomjegyzék}

Ambrus Á., Szeitzné Sz. M. (2010): Gabona alapú termékek mikotoxin szennyezettségének élelmiszerbiztonsági értékelése. Élelmiszer, Tudomány, Technológia, LXIV. (1), 10-14. o.

Brera, C., Catalano, C., De Santis, B., Debegnah, F., De Giacomo, M., Pannunzi, E. (2006): Effect of industrial processing on the distribution of aflatoxins and zearalenone in corn milling fractions. Journal of Agricultural and Food Chemistry, 54., pp. 5014-5019.

Frank P. (2010): Technológiai kísérletek a búza fuzárium toxin szennyezettségének csökkentésére. Élelmiszer Tudomány Technológia, LXIV. (2) különszám, 16-20. o.

Kiss Zs., Toldi J. (2013): Élelmiszertoxikológia. Jegyzet. Szegedi Tudományegyetem. 120. o. 
Kushiro M. (2008): Effects of Milling and cooking processes on the deoxynivalenol content in wheat. International Journal of Molecular Science, 9., pp. 2127-2145.

Mesterházy Á. (2007): Mikotoxinok a gabonatermesztésben: az élelmiszerbiztonsági kihívás. Élelmiszervizsgálati közlemények, LIII. kötet, (53 különszám), 38-48. o.

Sándor M., Győri Z., Sípos P. (2010): Malomipari lehetőségek értékelése az őszi búza mikotoxin szennyezettségének csökkentésében. Élelmiszer Tudomány Technológia, LXIV. (2) 4-9. o.

Sohár P-né. (2007): Mikotoxinok az élelmiszerláncban. Élelmiszervizsgálati közlemények. Különszám. LIII. kötet, (53. különszám), 60-68. o.

Szabó-Hevér Á. (2013): A kalászfuzárium rezisztencia molekuláris hátterének vizsgálata frontana eredetü térképező búzapopulációkban, SZIE, Doktori értekezés, 141. o.

Szeitzné Szabó M. (szerk.) (2009): Gabonaalapú élelmiszerek fuzárium toxin szennyezettségének csökkentési lehetőségei. Magyar Élelmiszerbiztonsági Hivatal, Budapest, 33. o.

Veres E., Borbély M. (2007): Az őszi búza felhasználhatósága a vizuális és mikrobiológiai Fusarium fertőzöttség-, valamint a toxin vizsgálatok alapján. Agrártudományi közlemények, (12), 26-34. 0 .

Véha A., Szabó P. B., Gyimes E. (2011): Peritec technology to reduce fusarium toxin in the milling technology. Analecta Technica Szegediensia, pp. 131-136. ISSN 1788-6392,

A Bizottság 1881/2006/EK rendelete (2006. december 19.) az élelmiszerekben előforduló egyes szennyező anyagok felső határértékeinek meghatározásáról

A Bizottság 2006/583/EK ajánlása (2006. augusztus 17.) a gabonákban és gabonakészítményekben a Fusarium-toxin-szennyezés megelőzéséről és csökkentéséről 